\title{
EVALUASI KEPUASAN PENGGUNA SIAKAD UNIVERSITAS TANJUNGPURA MENGGUNAKAN INTEGRASI TECHNOLOGY ACCEPTANCE MODEL (TAM) DAN END-USER COMPUTING SATISFACTION (EUCS)
}

\author{
Khairun Nisa Masitah ${ }^{1}$, Ilhamsyah ${ }^{2}$ \\ ${ }^{[1][2]}$ JurusanSistem Informasi, Fakultas MIPA Universitas Tanjungpura \\ Jl. Prof. Dr. H. Hadari Nawawi, Pontianak \\ Telp./Fax.:(0561) 577963 \\ Email : ${ }^{1}$ khairunnisa18@student.untan.ac.id, ${ }^{2}$ ilhamsyah@sisfo.untan.ac.id,
}

\begin{abstract}
Abstrak
Perkembangan kebutuhan teknologi menuntut perguruan tinggi untuk senantiasa mengembangkan layanan akademik yang dapat tersedia secara digital. Universitas Tanjungpura menggunakan SIAKAD untuk memenuhi kebutuhan informasi akademik. Penelitian ini bertujuan untuk mengevaluasi kepuasan pengguna SIAKAD Universitas Tanjungpura menggunakan integrasi TAM dan EUCS. Subjek penelitian yang digunakan adalah mahasiswa, dosen, dan operator akademik yang diperoleh responden sebanyak 318 dari metode random sampling di Universitas Tanjungpura. Pengujian yang dilakukan menggunakan perhitungan analisis PLS-SEM. Penelitian ini mengukur tingkat kepuasan pengguna melalui 8 kriteria hasil integrasi TAM dan EUCS yaitu kemanfaatan, kemudahan penggunaan, akurasi, kemudahan, dan ketepatan waktu, isi, format dan sikap. Dilakukan pengukuran menggunakan PLSSEM dengan 2 metode yaitu model pengukuran dan model struktural. Hasil hipotesis yang diterima atau mempengaruhi kepuasan pengguna adalah content, format dan attitude, masing-masing nilai tersebut adalah 2,736, 6,339, dan 5,240. Pada model struktural menghasilkan path coefficients yang bernilai besar yaitu content, format, dan attitude, masing-masing nilai tersebut adalah 0,217, 0,484, dan 0,372, semakin tinggi nilai t-statistik maka nilai path coefficients akan bernilai besar.
\end{abstract}

\section{PENDAHULUAN}

Perkembangan teknologi informasi dalam dunia pendidikan mempermudah dalam melakukan aktivitas akademik secara online. Penggunaan sistem informasi akademik berbasis web, dapat diakses melalui suatu jaringan internet yang diintegrasikan dengan sistem-sistem lainnya, seperti e-learning, sistem informasi monitoring dan evaluasi, SMS akademik dan sistem-sistem pendukung yang sesuai dengan kebutuhan akademik. Teknologi Informasi yang digunakan untuk kebutuhan pendidikan adalah Sistem Informasi Akademik (SIAKAD). SIAKAD akan memberikan kemudahan dalam mengelola data akademik. Pengembangan SIAKAD tidak lepas dari kepentingan pengguna yang terlibat dalam implementasi dan penggunaan sistem tersebut [1].

Universitas Tanjungpura menggunakan SIAKAD yang berada di bawah Unit Pelayanan Teknis Teknologi Informasi dan Komputer (UPT TIK). SIAKAD memiliki beberapa pengguna yaitu dosen, mahasiswa, operator akademik. Pemanfaatan SIAKAD
Universitas Tanjungpura sudah mengikuti perkembangan teknologi informasi dalam menjalankan fungsi akademiknya, dengan meningkatkan kualitas serta kemudahan untuk penggunanya. Terdapat beberapa fungsi atau layanan dari SIAKAD berupa pengelolaan Lembar Isian Rencana Studi (LIRS), Lembar Isian Hasil Studi (LIHS), Transkip Nilai, Kartu Tanda Mahasiswa (KTM) dan beberapa fasilitas yang dapat dilakukan oleh mahasiswa, dosen dan operator akademik yang memiliki hak akses.

Keberhasilan penerapan dari sistem informasi yaitu kepuasan pengguna akhir sistem tersebut. Untuk mengukur sistem informasi, organisasi harus mengetahui sikap kepuasan pengguna sebagai umpan balik untuk mengembangkan sistem informasi tersebut. Sehingga jika nilai kepuasan pada suatu sistem besar, maka kepuasan pengguna terhadap sistem juga menjadi besar hasilnya [2].

Sehingga, diperlukanya evaluasi kepuasan pengguna SIAKAD Universitas Tanjungpura menggunakan integrasi TAM dan EUCS. Penelitian ini bertujuan untuk mengukur variabel-variabel yang dinilai 
mempengaruhi kepuasan pengguna SIAKAD yaitu kemanfaatan (usefulness), kemudahan penggunaan (ease of use), Bentuk (format), Kemudahan (ease), Isi (content), Akurasi (accuracy), dan Ketepatan Waktu (timeliness) serta mengevaluasi kepuasan pengguna dengan memberikan hipotesis yang akan menghasilkan nilai akhir dari variabel pengukuran dapat diterima atau ditolak.

\section{LANDASAN TEORI}

\subsection{Konsep Sistem Informasi}

Sebuah sistem terdiri atas komponen dalam satu tujuan, model dasar bentuk sebuah sistem berupa masukan, pengolahan, dan keluaran. Sistem terbagi menjadi dua jenis dalam lingkungannya yaitu sistem tertutup dan terbuka, akan tetapi sistem informasi biasanya bersifat sistem terbuka. Sehingga sistem tersebut dapat menerima masukan dari lingkungan luarnya.

Transformasi informasi merupakan komponen pengolahan sistem yang berfungsi memproses data menjadi informasi yang diperlukan oleh pengguna. Proses transformasi akan bertitik tolak dari data yang dikumpulkan oleh sumber dengan menggunakan instrumen pengumpul, selanjutnya data diolah, dianalisis, dan ditafsirkan dengan cara tertentu. Sehingga data yang diproses menghasilkan suatu informasi [1].

\subsection{Sistem Informasi Akademik (SIAKAD)}

Sistem Informasi Akademik merupakan sistem yang memberikan layanan informasi berupa data yang berhubungan dengan akademik. Dimana dalam hal ini pelayanan yang diberikan seperti penyimpanan data siswa, penentuan kelas, penentuan jadwal pelajaran. Sistem Informasi Akademik terkenal dengan perangkat lunak untuk menyajikan informasi dan menata administrasi yang berhubungan dengan kegiatan akademis [2].

\subsection{Kepuasan pengguna Sistem Informasi}

Kepuasan pengguna (user satisfaction) sebagai umpan balik dari pengguna setelah menggunakan sistem informasi. Sikap pengguna sesudah menggunakan sistem informasi merupakan kriteria subjektif atau tingkat kepuasan pengguna terhadap sistem yang digunakan. [3].

\subsection{Technology Acceptance Model (TAM)}

Model TAM dikembangkan dari model Theory of Reasoned Action (TRA) yaitu tindakan beralasan dengan satu premis bahwa persepsi dan reaksi seseorang terhadap sesuatu hal, sehingga menentukan perilaku dan sikap orang tersebut. Faktor yang mempengaruhinya yaitu persepsi pengguna terhadap kemudahan dan kemanfaatan penggunaan [4].

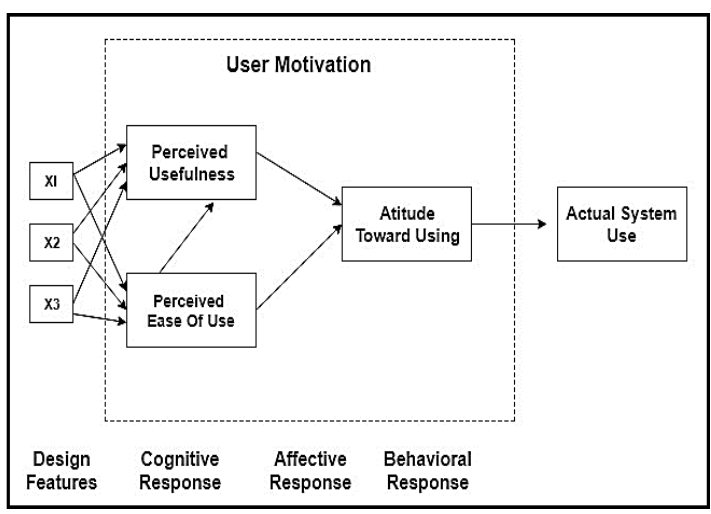

Gambar 1. Model Dasar Technology Acceptance Model [4].

Model dasar TAM pada Gambar 1, terdapat anak panah sebagai hubungan sebab akibat, sikap terhadap penggunaan merupakan fungsi dari dua faktor penting yaitu kemanfaatan dan kemudahan penggunaan. Fitur desain akan mempengaruhi kemanfaatan dan kemudahan penggunaan, karena fitur desain merupakan kategori variabel ekternal yang tidak memiliki efek langsung pada sikap atau perilaku. Sikap pengguna mengacu pada penggunaan aktual seseorang secara langsung atas sistem yang digunakan [4].

Model TAM klasik tidak dapat digunakan dalam lingkungan mandatory use. Model TAM klasik sebaiknya diterapkan pada lingkungan voluntary use. Perbedaan sifat mandatory use atau voluntary use terletak pada kebebasan penggunaan sistem oleh pemakainya. Voluntary use akan memberikan kebebasan (freedom) pemakai untuk memutuskan tidak menggunakan atau menggunakan sistem informasi tersebut. Dan sebaliknya, mandatory use pemakai tidak memiliki kebebasan untuk menentukan pilihan tersebut karena diwajibkan menggunakan sistem oleh perusahaan atau lembaga yang menerapkan sistem informasi tersebut [5]. 
SIAKAD sebagai target penelitian, pada penggunaan sistem informasi yang bersifat mandatory use. Karena pengguna wajib menggunakan sistem dan tidak memiliki pilihan lain selain menggunakan SIAKAD dalam proses akademiknya. Jika objek penelitian menggunakan sistem informasi bersifat mandatory use, maka intensitas penggunaan SIAKAD otomatis menjadi $100 \%$.

\subsection{End User Computing Satisfaction (EUCS)}

End User Computing Satisfaction (EUCS) mengukur kepuasan akhir terhadap aspek teknologi berdasarkan content, accuracy, format, ease, dan timeliness. End User Computing Satisfaction (EUCS) merupakan suatu metode yang digunakan untuk mengukur tingkat kepuasan pengguna sebuah sistem dengan memberikan perbandingan terhadap harapan dan kenyataan dari sebuah sistem informasi. Definisi End User Computing Satisfaction (EUCS) dari sebuah sistem informasi yaitu pengguna memberikan evaluasi secara keseluruhan berdasarkan pengalaman pengguna setelah menggunakan sistem tersebut [6].

\subsection{Populasi dan Sampel}

Populasi terdiri dari subjek atau objek yang memiliki suatu kuantitas dan karakteristik yang sudah ditentukan yang akan ditarik kesimpulannya. Populasi tidak hanya orang, akan tetapi objek atau benda-benda alam lain. Sampel adalah suatu bagian dari karakteristik dan jumlah yang terdapat pada populasi. Jika populasi cukup besar maka tidak memiliki waktu untuk mengambil seluruh populasi sebaiknya memakai sampel yang diambil dari populasi tersebut [7].

\subsection{Teknik Sampling}

Pada metode penarikan sampel terbagi menjadi dua jenis yaitu pemilihan sampel secara tidak acak (non random atau nonprobability sampling) dan secara acak (random atau probability sampling) Pembagian teknik sampling terdapat pada Gambar 2. [8]:

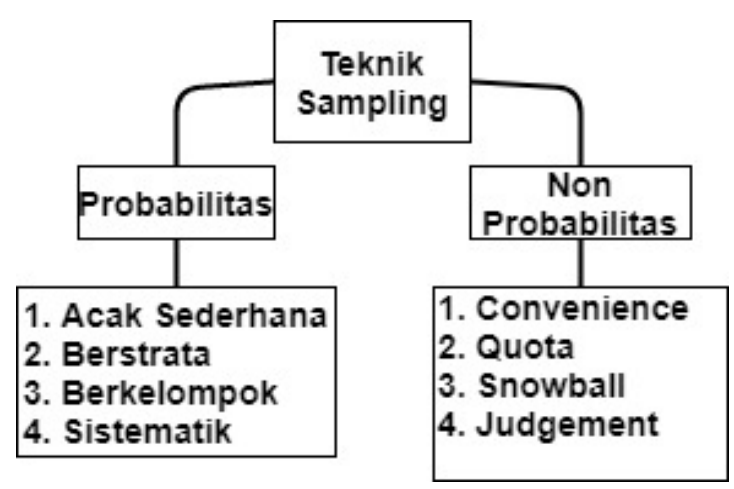

Gambar 2. Teknik Sampling [8]

\subsection{Skala Likert}

Skala likert adalah skala pengukuran intensitas sikap atau perasaan responden. Untuk pengukuran skala likert instrument harus didesain, yang pada umumnya menggunakan pertanyaan (kuisioner) dengan lima alternatif jawaban secara berjenjang. Jenjang jawaban dalam skala likert terdapat pada Tabel 1 [9].

Tabel 1 Skala Likert

\begin{tabular}{|l|c|}
\hline \multicolumn{1}{|c|}{ Jawaban } & Bobot \\
\hline Sangat Tidak Setuju & 1 \\
\hline Tidak Setuju & 2 \\
\hline Kurang Setuju & 3 \\
\hline Setuju & 4 \\
\hline Sangat Setuju & 5 \\
\hline
\end{tabular}

\subsection{Data Kualitatif dan Kuantitatif}

Data kuantitatif adalah data yang berupa angka atau rasio yang dapat diklasifikasikan sebagai data kuantitatif. Sebagai contoh, pada umumnya pengambilan sampel dilakukan secara, sehingga pengumpulan data akan menggunakan instrumen penelitian, analisis data bersifat statistik atau kuantitatif dengan tujuan untuk menguji hipotesis yang telah ditentukan. Data kualitatif merupakan data yang sifatnya hanya menggolongkan saja. Data yang berskala ordinal dan nominal merupakan klasifikasi data kualitatif [8].

\subsection{Variabel Penelitian}

Penelitian ini membagi variabel menjadi dua jenis yaitu, variabel independen (variabel bebas) dan variabel dependen (variabel terikat). Variabel independen adalah variabel yang menjadi sebab perubahan atau variabel yang mempengaruhi variabel dependen. Sedangkan variabel dependen adalah variabel yang menjadi akibat adanya variabel independen 
atau variabel yang dipengaruhi oleh variabel independen [10].

Penelitian ini menggunakan enam variabel independen atau variabel bebas yaitu kemanfaatan (usefullness), kemudahan penggunaan (ease of use), isi (content), Akurasi (accuracy), format (format), kemudahan penggunaan (ease), ketepatan waktu (timeless), dan menggunakan dua variabel dependen atau variabel sikap (attitude) dan kepuasan pengguna (user satisfaction).

\subsection{PLS-SEM (Partial Least Square Structural Equation Modeling)}

PLS-SEM terbagi menjadi dua model analisis yaitu model pengukuran (outer model) dan model struktural (inner model). Sehingga setiap tahapan memiliki skala pengukuran dalam menentukan nilai atau besaran ukuran statistik terhadap evaluasi kepuasan pengguna. Berikut ini merupakan penjelasan tahapan model pengukuran (outer model) dan model struktural (inner model). Pada analisis model pengukuran (outer model) memiliki empat tahap pengukuran yaitu loading factor, Composite Reliability, Average Variance Extracted (AVE), Discriminant validity. [11].

\section{a. Loading factor}

Loading factor akan merupakan besarnya korelasi antara setiap item pengukuran (indikator) dengan konstruknya. Untuk nilai loading factor $>0.7$ dikatakan ideal, sehingga indikator tersebut dikatakan valid untuk mengukur konstruknya. Berikut ini merupakan persamaan menghitung nilai Loading factor [11]:

Indikator untuk variable independen

$$
x=\Lambda_{x} \xi+\varepsilon_{x}
$$

Indikator untuk variable dependen

$$
y=\Lambda_{\nu} \eta+\varepsilon_{\gamma}
$$

Dimana $\mathrm{x}$ dan $\mathrm{y}$ merupakan indikator untuk variable independen dan dependen $\xi$ dan $\eta$, sedangkan $\Lambda_{\chi}$ dan $\Lambda_{\gamma}$ adalah merupakan matrik loading yang menggambarkan koefisien regresi sederhana yang menghubugkan variable laten dengan indikatornya dan $\varepsilon_{\chi}, \varepsilon_{\gamma}$ dapat diinterpretasikan sebagai kesalahan pengukuran.

\section{b. Average Variance Extracted (AVE)}

Pada pengukuran nilai AVE memiliki batas minimal 0.5 yang artinya ukuran convergent validity yang baik. Pada persamaan 3 dimana גi adalah component loading ke indikator dan $\operatorname{var}(\varepsilon \mathrm{i})=1-\mathrm{\lambda i}^{2}$. Berikut ini merupakan persamaan menghitung nilai AVE [11]:

$$
A V E=\frac{\sum \mathrm{xi}^{2}}{\sum \mathrm{xi}^{2}+\sum \mathrm{i} \operatorname{var}(\varepsilon \mathrm{i})}
$$

\section{c. Discriminant validity}

Discriminant validity akan dievaluasi melalui cross loading, kemudian nilai AVE dibandingkan dengan kuadrat dari nilai korelasi antar variabel. Nilai cross loading akan membandingkan korelasi indikator dengan variabelnya dan variabel dari blok lainnya. Jika korelasi antara indikator terhadap variabelnya lebih tinggi dari korelasi dengan variabel blok lainnya, hal ini menunjukkan variabel tersebut memprediksi ukuran pada blok mereka dengan lebih baik dari blok lainnya. Pengukuran discriminant validity lainnya yaitu melihat nilai akar AVE harus lebih tinggi terhadap korelasi antara variabel dengan variabel lainnya atau nilai AVE lebih tinggi dari kuadrat korelasi antara variabel.

\section{d. Composite Reliability}

Langkah selanjutnya melihat interpretasi composite reliability dengan nilai batas minimal 0.7 dapat diterima, dan nilai composite reliability diatas 0.8 sangat memuaskan. Berikut ini merupakan persamaan 4 menghitung nilai composite reliability [11] :

$$
p c=\frac{\left(\sum \mathrm{ii}\right)^{2}}{\left(\sum \mathrm{i}\right)^{2}+\sum \mathrm{i} v \operatorname{var}(\varepsilon \mathrm{i})}
$$

Dimana $\lambda_{1}$ adalah component loading ke indikator dan $\operatorname{var}(\varepsilon \mathrm{i})=1-\mathrm{\lambda i}^{2}$. Dibandingkan dengan Cronbach alpha cenderung lower bound estimate realibility sedangkan composite reliability hanya dapat digunakan untuk indikator reflektif.

Sedangkan model struktural (inner model) memiliki 4 pengujian yaitu Path Coefficients, Uji T-Statistik, Uji koefisien $\left(\mathrm{R}^{2}\right)$, dan Uji Effect Size $\left(\mathrm{f}^{2}\right)$ [11].

\section{a. Path Coefficients, Uji T-Statistik,}

Penerapan dengan resampling akan memungkinkan berlakunya data terdistribusi bebas, tidak memerlukan asumsi distribusi normal, dan sampel dengan ukuran kecil (direkomendasikan sampel minimum 30). Path Coefficients digunakan untuk melihat nilai estimasi hubungan jalur variabel dalam 
model struktural. Untuk menentukan suatu hipotesis itu dapat ditolak atau diterima diantaranya dengan memperhatikan nilai signifikansi antar variabel, Sehingga hipotesis akan diterima jika uji t-statistik > 1.96 dengan tingkat signifikansi (5\%).

\section{b. Uji koefisien $\left(\mathrm{R}^{2}\right)$}

Perubahan nilai $\mathrm{R}^{2}$ dapat digunakan untuk melihat apakah pengaruh variabel laten independen terhadap variabel laten dependen memiliki pengaruh yang substantif. Klasifikasi nilai $\mathrm{R}^{2}$ dapat dilihat pada tabel 2 sebagai berikut.

Tabel 2 Klasifikasi nilai $\mathrm{R}^{2}$

\begin{tabular}{|c|c|}
\hline Nilai & Klasifikasi \\
\hline $0.67-1$ & Besar \\
\hline $0.33-0.66$ & Sedang \\
\hline $0-0.32$ & Kecil \\
\hline
\end{tabular}

\section{c. Uji Effect Size $\left(\mathrm{f}^{2}\right)$}

Formulasi effect size $\mathrm{f}^{2}$ adalah :

$$
\begin{aligned}
& \text { Effect Size } \mathrm{f}^{2}= \\
& \mathrm{R}_{\text {Included }}^{2}-\mathrm{R}^{2} \text { Excluded }: 1-\mathrm{R}^{2} \text { Included }
\end{aligned}
$$

Dimana $\mathrm{R}^{2}$ included dan $\mathrm{R}^{2}$ excluded merupakan $\mathrm{R}^{2}$ dari variabel laten dependen yang diperoleh ketika variabel independen tersebut masuk atau dikeluarkan dalam model. Klasifikasi Effect Size $\mathrm{f}^{2}$ yang disarankan terdapat pada tabel 3 sebagai berikut.

Tabel 3 Klasifikasi nilai Effect Size $\mathrm{f}^{2}$

\begin{tabular}{|c|c|}
\hline Nilai & Klasifikasi \\
\hline $0.35-1$ & Besar \\
\hline $0.15-0.34$ & Sedang \\
\hline $0-0.14$ & Kecil \\
\hline
\end{tabular}

\subsection{SmartPLS}

SmartPLS merupakan software yang digunakan dalam analisis menggunakan PLSSEM, software ini dikembangkan oleh University of Hamburg, Jerman. SmartPLS sebagai proyek di Institute Of Operation Management And Organization dan menggunakan Java Webstart Technology). [11].

\section{METODOLOGI PENELITIAN}

Dalam penelitian ini menggunakan metode hevner dalam kerangka kerja penelitian yang dapat dilihat pada Gambar 3 :

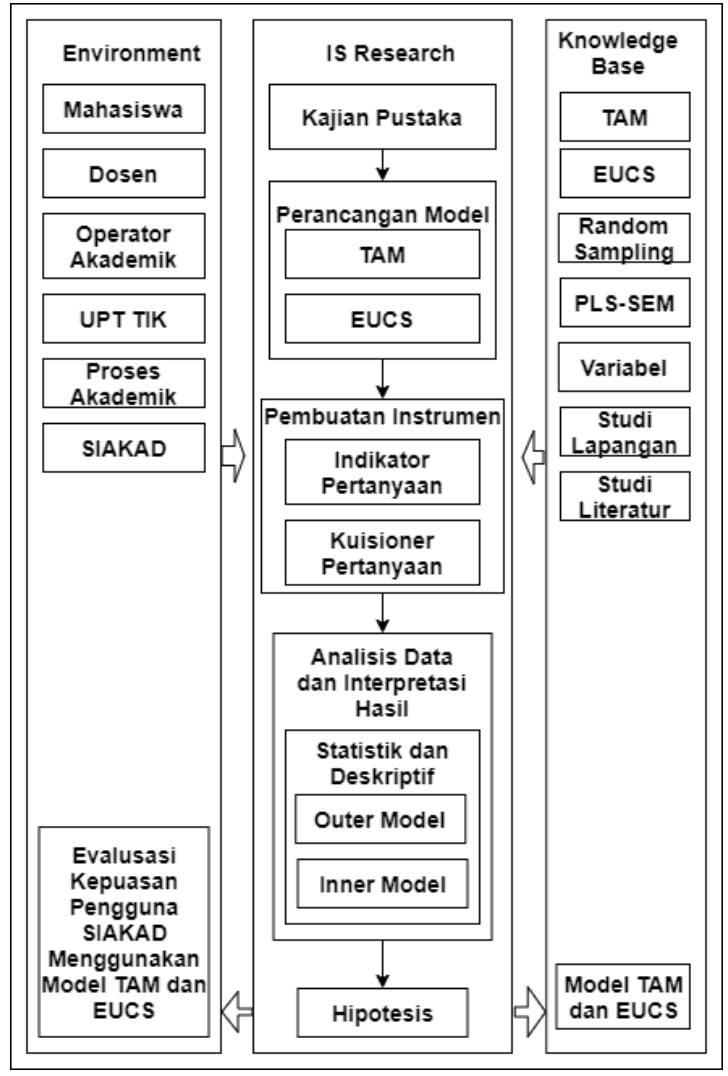

Gambar 3 Kerangka Kerja Penelitian

\section{ANALISIS DAN PERANCANGAN}

\subsection{Integrasi Model}

Integrasi model yaitu dengan mengabungkan dua model TAM dan EUCS, yang dilakukan pada penelitian sebelumnya yaitu model perancangan Sukendera [12]. TAM mengasumsikan penerimaan teknologi informasi ditentukan oleh dua faktor, yaitu kemanfaatan (usefulness) dan kemudahan penggunaan (ease of use). Sehingga model TAM dapat dilihat pada Gambar 4 :

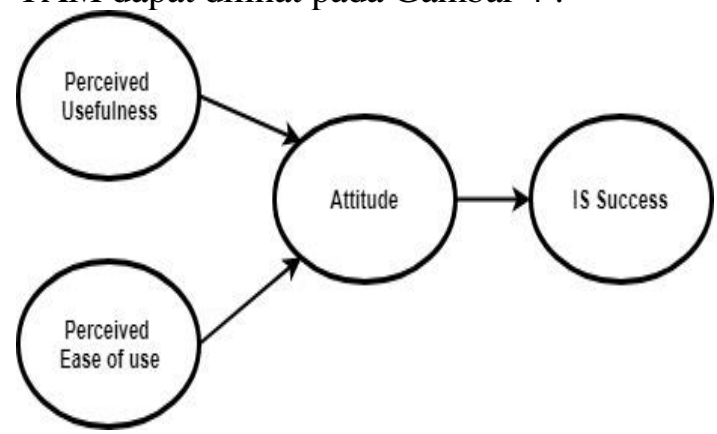

Gambar 4. Pengembangan Model Technology Acceptance Mandatory Use [11]

Penelitian ini menggunakan model TAM dengan menghilangkan intention to use sebagai intensitas pengguna SIAKAD yang dipergunakan oleh kampus untuk menunjang 
proses akademiknya. Sedangkan intention to use tidak dipergunakan dalam lingkungan mandatory use. Karena pengguna wajib menggunakan sistem dan tidak memiliki pilihan lain selain menggunakan sistem SIAKAD dalam proses akademiknya. Actual system use tidak dipergunakan dalam mengukur kepuasan pengguna karena Actual system use berada di lingkungan voluntary use. Lingkungan mandatory use menggunakan user satisfaction dalam mengukur kepuasan pengguna. Sehingga user satisfaction digunakan sebagai tujuan utama penelitian dalam mengukur kepuasan pengguna SIAKAD [5].

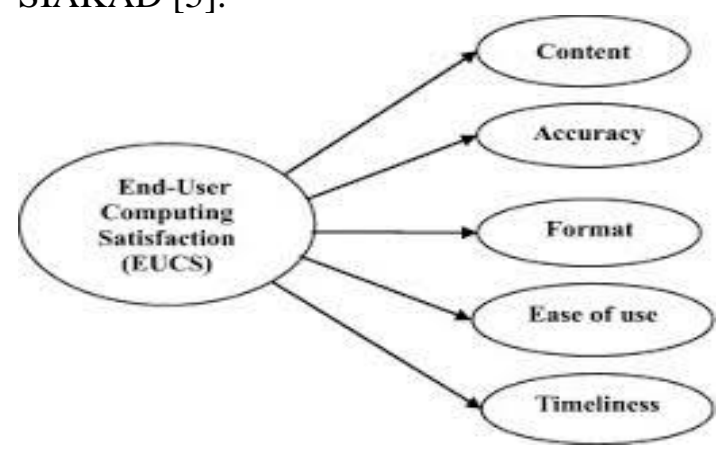

Gambar 5. Model Evaluasi End User Computing Satisfaction (EUCS) [6].

Pada Gambar 5. merupakan End User Computing Satisfaction (EUCS) dengan menekankan beberapa faktor yang mempengaruhi user satisfaction yaitu content, accurac, format, ease, dan timelines. [6].

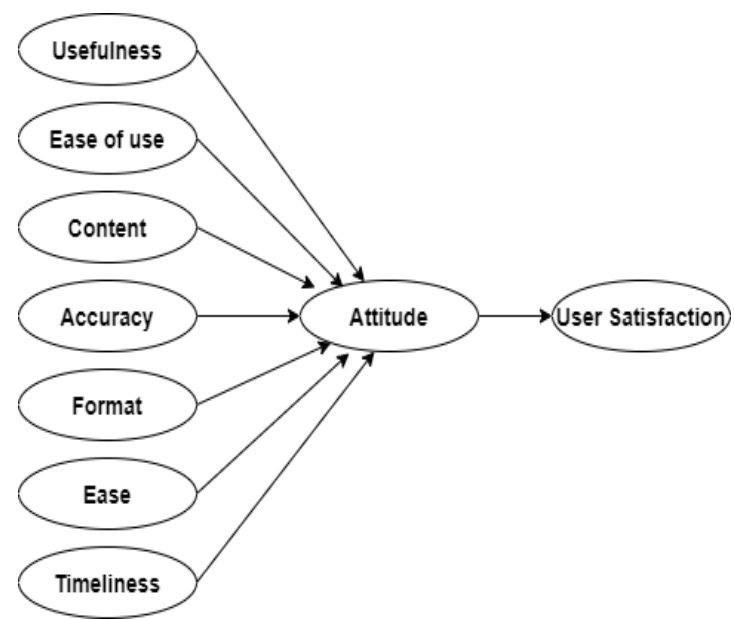

Gambar 6. Integrasi Konsep TAM dan EUCS

[12].

Pada Gambar 6. integrasi TAM dan EUCS memiliki dua variabel yang sama yaitu ease of use dan ease yang memiliki indikator berbeda dalam pengukurannya. sehingga memiliki tujuh variabel integrasi TAM dan EUCS yang terdiri dari usefulness, ease of use, content, accuracy, format, ease, dan timelines. Ketujuh variabel tersebut kemudian dihipotesiskan mempengaruhi sikap terhadap penggunaan sistem (attitude). Selanjutnya attitude akan mempengaruhi kepuasan penggunaan sistem (user satisfaction).

\subsection{Hipotesis}

Hipotesis pada penelitian berdasarkan evaluasi analisis model struktural (inner model) yang dihasikan dari nilai signifikan hubungan antar variabel untuk menentukan hipotesis nol $\left(\mathrm{H}_{0}\right)$ ditolak dan hipotesis alternatif $\left(\mathrm{H}_{\mathrm{a}}\right)$ dapat diterima. Untuk variabel yang memiliki pengaruh positif terhadap sikap pengguna sistem dan signifikan dengan kepuasan pengguna SIAKAD memiliki nilai t-statistik > 1.96 maka hipotesis nol $\left(\mathrm{H}_{0}\right)$ ditolak dan hipotesis alternatif $\left(\mathrm{H}_{\mathrm{a}}\right)$ diterima.

Sedangkan jika variabel tidak memiliki pengaruh positif terhadap sikap pengguna sistem dan signifikan dengan kepuasan pengguna SIAKAD memiliki nilai t-statistik $<1.96$ maka hipotesis nol $\left(\mathrm{H}_{0}\right)$ diterima dan hipotesis alternatif $\left(\mathrm{H}_{\mathrm{a}}\right)$ ditolak.

\subsection{Instrumen Penelitian}

Instrumen pada penelitian ini merupakan alat yang digunakan dalam mengumpulkan data untuk mengetahui kepuasan pengguna SIAKAD. Uraian indikator variabel independen TAM dan EUCS dapat dilihat pada Table 4.

Tabel 4. Indikator Independen Variabel TAM dan EUCS

\begin{tabular}{|c|c|c|}
\hline Model & Variabel & Indikator \\
\hline \multirow{4}{*}{ TAM } & \multirow{4}{*}{$\begin{array}{l}\text { Kemanfaatan } \\
\text { (Usefulness) }\end{array}$} & $\begin{array}{l}\text { SIAKAD berbagi } \\
\text { informasi lebih } \\
\text { cepat [9], [12] }\end{array}$ \\
\hline & & $\begin{array}{l}\text { SIAKAD } \\
\text { meningkatkan } \\
\text { Kinerja [9], [11], } \\
{[12]}\end{array}$ \\
\hline & & $\begin{array}{l}\text { SIAKAD membuat } \\
\text { pekerjaan lebih } \\
\text { mudah (Makes Job } \\
\text { Easier) [9], [11] }\end{array}$ \\
\hline & & $\begin{array}{l}\text { SIAKAD } \\
\text { meningkatkan } \\
\text { kemampuan dalam } \\
\text { mencari informasi }\end{array}$ \\
\hline
\end{tabular}


Tabel 4. Indikator Independen Variabel TAM dan EUCS (lanjutan)

\begin{tabular}{|c|c|c|}
\hline \multirow[b]{2}{*}{ Model } & \multirow{2}{*}{\multicolumn{2}{|c|}{ Indikator }} \\
\hline & & \\
\hline TAM & $\begin{array}{r}\text { Kemanfaatan } \\
\text { (Usefulness) }\end{array}$ & $\begin{array}{l}\text { SIAKAD } \\
\text { memberikan } \\
\text { informasi yang } \\
\text { berguna [9], [11] }\end{array}$ \\
\hline & \multirow{4}{*}{$\begin{array}{l}\text { Kemudahan } \\
\text { penggunaan } \\
(\text { Ease of use) }\end{array}$} & $\begin{array}{l}\text { Fitur SIAKAD sudah } \\
\text { mudah dipahami oleh } \\
\text { pengguna [9], [11] }\end{array}$ \\
\hline & & $\begin{array}{l}\text { SIAKAD mudah } \\
\text { untuk dioperasikan } \\
{[9],[11] .}\end{array}$ \\
\hline & & $\begin{array}{l}\text { SIAKAD mudah } \\
\text { diakses ketika } \\
\text { digunakan [9], [11] }\end{array}$ \\
\hline & & $\begin{array}{l}\text { Fasilitas SIAKAD } \\
\text { sudah menyediakan } \\
\text { fasilitas yang } \\
\text { mendukung seperti } \\
\text { pengguna di leptop } \\
\text { dan android [9], } \\
\text { [11]. }\end{array}$ \\
\hline \multirow{7}{*}{ EUCS } & \multirow{4}{*}{$\begin{array}{c}\text { Isi } \\
(\text { Content })\end{array}$} & $\begin{array}{l}\text { SIAKAD sudah } \\
\text { menyediakan } \\
\text { informasi sesuai } \\
\text { kebutuhan pengguna } \\
{[5],[11],[13]}\end{array}$ \\
\hline & & $\begin{array}{l}\text { Isi dari informasi } \\
\text { SIAKAD sudah } \\
\text { sesuai kebutuhan. } \\
{[5],[11],[12]} \\
\end{array}$ \\
\hline & & $\begin{array}{l}\text { SIAKAD sudah } \\
\text { menampilkan hasil } \\
\text { pencarian informasi } \\
\text { yang dibutuhkan oleh } \\
\text { pengguna. } \\
{[5],[11]}\end{array}$ \\
\hline & & $\begin{array}{l}\text { SIAKAD sudah } \\
\text { mampu memenuhi } \\
\text { kebutuhan informasi } \\
\text { pengguna. [5], [11] }\end{array}$ \\
\hline & \multirow[b]{2}{*}{$\begin{array}{l}\text { Ketepatan } \\
\text { (Accuracy) }\end{array}$} & $\begin{array}{l}\text { Informasi dalam } \\
\text { SIAKAD sudah } \\
\text { akurat [5], [12], [13] }\end{array}$ \\
\hline & & $\begin{array}{l}\text { Akurasi didalam } \\
\text { SIAKAD } \\
\text { memberikan } \\
\text { kepuasan. } \\
{[5],[11],[12]}\end{array}$ \\
\hline & $\begin{array}{l}\text { Bentuk } \\
\text { (Format) }\end{array}$ & $\begin{array}{l}\text { Informasi yang } \\
\text { ditampilkan SIAKAD } \\
\text { dengan format yang } \\
\text { baik. [5], [11] }\end{array}$ \\
\hline
\end{tabular}

Tabel 4. Indikator Independen Variabel TAM dan EUCS (lanjutan)

\begin{tabular}{|c|c|c|}
\hline Model & Variabel & Indikator \\
\hline & & $\begin{array}{l}\text { Informasi yang } \\
\text { diberikan sudah jelas } \\
\text { dan tidak membingun } \\
\text { gkan }[5],[11],[12]\end{array}$ \\
\hline & \multirow[b]{2}{*}{$\begin{array}{c}\text { Kemudahan } \\
\text { (Ease) }\end{array}$} & $\begin{array}{l}\text { dokumen, tulisan } \\
\text { yang mudah dibaca } \\
\text { dan ramah pengguna. } \\
{[5],[11]}\end{array}$ \\
\hline & & $\begin{array}{l}\text { SIAKAD merupakan } \\
\text { sistem yang mudah } \\
\text { digunakan jika } \\
\text { terdapat perubahan } \\
\text { atau update sistem } \\
\text { yang lebih baik [5], } \\
\text { [11] }\end{array}$ \\
\hline & \multirow[t]{2}{*}{$\begin{array}{l}\text { ketepatan } \\
\text { waktu } \\
\text { (timeless) }\end{array}$} & $\begin{array}{l}\text { SIAKAD memberikan } \\
\text { keluaran informasi } \\
\text { secara tepat waktu [5], } \\
\text { [11] }\end{array}$ \\
\hline & & $\begin{array}{l}\text { SIAKAD } \\
\text { memberikan } \\
\text { informasi terbaru [5], } \\
{[11],[13]}\end{array}$ \\
\hline
\end{tabular}

Sedangkan variabel dependen dari sikap (attitude) dan kepuasan pengguna (user satisfaction) dapat dilihat pada Tabel 5 :

Tabel 5. Indikator Variabel Dependen

\begin{tabular}{|c|l|}
\hline Variabel & \multicolumn{1}{|c|}{ Indikator } \\
\hline \multirow{3}{*}{$\begin{array}{c}\text { Sikap } \\
\text { Attitude })\end{array}$} & $\begin{array}{l}\text { Ide yang bagus ketika SIAKAD } \\
\text { digunakan untuk kebutuhan } \\
\text { akademik pengguna. [9], [12] }\end{array}$ \\
\cline { 2 - 2 } & $\begin{array}{l}\text { SIAKAD membuat pekerjaan } \\
\text { menjadi lebih menarik }\end{array}$ \\
\cline { 2 - 2 } & $\begin{array}{l}\text { Bekerja menggunakan SIAKAD } \\
\text { sangat menyenangkan. [9], [14] }\end{array}$ \\
\hline \multirow{2}{*}{$\begin{array}{c}\text { kepuasan } \\
\text { pengguna } \\
\text { (User }\end{array}$} & $\begin{array}{l}\text { Pengguna sangat bergantung } \\
\text { dengan Layanan SIAKAD dalam } \\
\text { proses akademik secara tepat }\end{array}$ \\
waktu. [15] \\
\cline { 2 - 2 } & $\begin{array}{l}\text { Pengguna puas dengan SIAKAD. } \\
{[12],[15]}\end{array}$ \\
\hline
\end{tabular}

\subsection{Pembahasan}

Analisis pengukuran model (outer model) dilakukan untuk menilai validasi dan realibilitas model. Responden pada penelitian ini merupakan Mahasiswa, Dosen, dan Operator akademik. Penyebaran kuisioner dilakukan pada tanggal 1 Desember 2019 dan menghasilkan 40 responden dengan status 
pengguna adalah mahasiswa Universitas Tanjungpura. Analisis pengukuran model (outer model) menggunakan PLS-SEM lewat program SmartPLS 3. Outer model terdiri dari loading factor, average variance extracted (AVE), discriminant validity dan Composite Reliability.

Hasil kesimpulan analisis model pengukuran (outer model) dapat dilihat pada Tabel 6 sebagai berikut.

Tabel 6. Hasil Analisis Model Pengukuran (Outer Model)

\begin{tabular}{|c|c|c|}
\hline No & Tahapan & Hasil \\
\hline 1. & $\begin{array}{c}\text { Loading } \\
\text { Factor }\end{array}$ & $\begin{array}{lll}\text { Hasil uji outer loading } & \text { sudah } \\
\text { valid diatas } 0.5 & \text { untuk } \\
\text { mengujian selanjutnya. } & \end{array}$ \\
\hline 2. & $\begin{array}{l}\text { Average } \\
\text { Variance } \\
\text { Extracte } \\
d(\mathrm{AVE})\end{array}$ & $\begin{array}{l}\text { Nilai AVE diatas } 0.50 \\
\text { menunjukkan ukuran } \\
\text { convergent validity yang baik. } \\
\text { Setelah nilai uji sudah valid } \\
\text { maka dilanjutkan dengan } \\
\text { pengujian selanjutnya. }\end{array}$ \\
\hline \multirow[t]{2}{*}{3.} & \multirow{2}{*}{$\begin{array}{l}\text { Discrimi } \\
\text { nant } \\
\text { validity }\end{array}$} & $\begin{array}{l}\text { Hasil dari discriminant validity } \\
\text { menggunakan tahap pengujian } \\
\text { nilai cross loading dan nilai } \\
\text { pada Fornel Lacker's, } \\
\text { dikatakan baik, memenuhi } \\
\text { syarat, tidak terdapat masalah } \\
\text { dan dapat dilakukan pengujian } \\
\text { selanjutnya }\end{array}$ \\
\hline & & $\begin{array}{l}\text { Hasilnya dilihat dari nilai cross } \\
\text { loading antara indikator } \\
\text { dengan variabelnya dan } \\
\text { membandingkan akar kuadrat } \\
\text { dari average variance } \\
\text { extracted (AVE) untuk setiap } \\
\text { variabel. }\end{array}$ \\
\hline 4. & $\begin{array}{l}\text { Composit } \\
e \\
\text { Reliabilit } \\
y\end{array}$ & $\begin{array}{lcr}\text { Hasil composite reliability } & \text { colar } \\
\text { dengan nilai semua variabel } \\
\text { diatas } 0.70 . & \text { Sehingga } \\
\text { pengujian ini memenuhi syarat } \\
\text { dan variabel memiliki } \\
\text { realibilitas yang baik. }\end{array}$ \\
\hline
\end{tabular}

Pada penyebaran kuisioner struktural model (inner Model), menghasilkan responden yang merupakan pengguna aktif SIAKAD dalam ruang lingkup Universitas Tanjungpura. Data responden dikumpulkan 5-6 Desember 2019 kemudian kuisioner disebarkan secara Random Sampling dan 85\% secara online, 15\% secara langsung., sehingga menghasilkan 318 responden dengan data valid. Pengujian model struktural dilakukan dengan 4 tahapan, yaitu Path Coefficients, Uji T-Statistik, Uji koefisien
$\left(\mathrm{R}^{2}\right)$, dan Uji Effect Size $\left(\mathrm{f}^{2}\right)$. Hasilnya dapat dilihat pada Tabel 7 dan Gambar 7.

Tabel 7. Hasil bootstrapping

\begin{tabular}{|l|r|}
\hline $\begin{array}{c}\text { Hubungan } \\
\text { variabel }\end{array}$ & $\begin{array}{c}\text { Path } \\
\text { coefficients }\end{array}$ \\
\hline $\mathrm{A}-\mathrm{H}$ & 0,011 \\
\hline $\mathrm{B}-\mathrm{H}$ & 0,048 \\
\hline $\mathrm{C}-\mathrm{H}$ & 0,217 \\
\hline $\mathrm{D}-\mathrm{H}$ & 0,004 \\
\hline $\mathrm{E}-\mathrm{H}$ & 0,484 \\
\hline $\mathrm{F}-\mathrm{H}$ & 0,012 \\
\hline $\mathrm{G}-\mathrm{H}$ & 0,100 \\
\hline $\mathrm{H}-\mathrm{I}$ & 0,372 \\
\hline
\end{tabular}

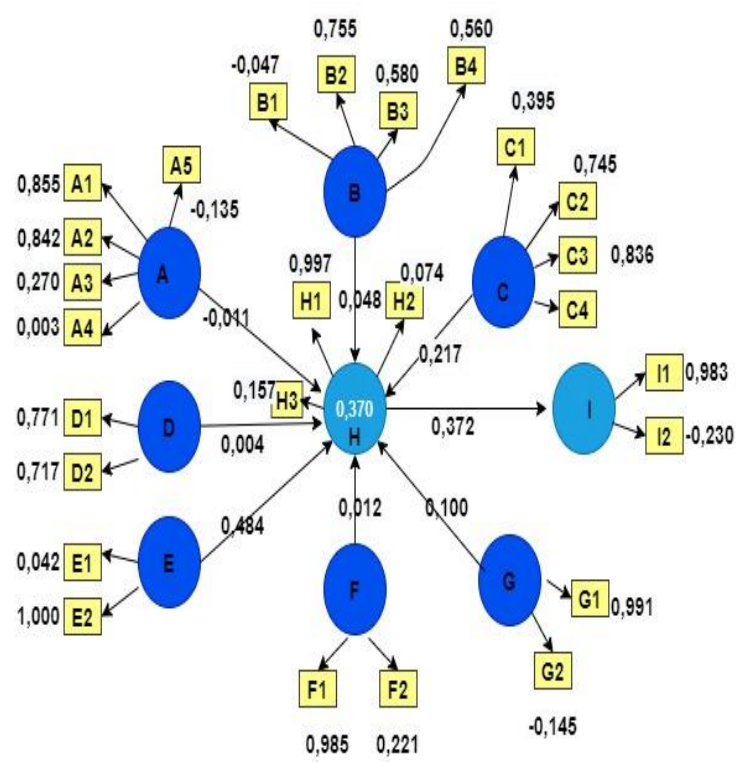

Gambar 7. Hasil bootstrapping

Pada Tabel 7 dan Gambar 7. merupakan hasil path coefficients semakin tinggi nilai nilai tstatistik maka path coefficients akan bernilai besar. 3 dari 8 variabel yang memiliki nilai besar, yaitu content, format, dan attitude, masig-masing nilai tersebut $0,217,0,484$, dan 0,372 .

Tabel 8. Hasil Uji Koefisien $\left(\mathrm{R}^{2}\right)$
\begin{tabular}{|l|r|}
\hline Variabel & R-Square $\left(\mathbf{R}^{2}\right)$ \\
\hline H & 0.370 \\
\hline I & 0,140 \\
\hline
\end{tabular}

Hasil nilai $R$-Square pada Tabel 8 diketahui nilai variabel $\mathrm{H}$ (attitude) dengan klasifikasi sedang yang berdasarkan pada tabel 2, nilai $\mathrm{H}$ (attitude) yang kecil karena dipengaruhi oleh setiap nilai variabel independen terhadap nilai dependen. 
Sedangkan variabel I (user satisfaction) dengan klasifikasi lemah, pada nilai I (user satisfaction) dipengaruhi oleh variabel $\mathrm{H}$ (attitude) yang terhubung variabel independen.

Tabel 9. Hasil effect size $\left(\mathrm{f}^{2}\right)$

\begin{tabular}{|c|c|c|c|c|}
\hline No & Variabel & $\mathbf{R}_{\text {include }}$ & $\mathbf{R}_{\text {exclude }}$ & $\begin{array}{c}\text { effect } \\
\text { size }\left(\mathbf{f}^{2}\right)\end{array}$ \\
\hline 1 & $\mathrm{~A}-\mathrm{H}$ & \multirow{7}{*}{0,37} & 0,37 & 0,000 \\
\hline 2 & $\mathrm{~B}-\mathrm{H}$ & & 0,368 & 0,003 \\
\hline 3 & $\mathrm{C}-\mathrm{H}$ & & 0,34 & 0,048 \\
\hline 4 & $\mathrm{D}-\mathrm{H}$ & & 0,37 & 0,000 \\
\hline 5 & $\mathrm{E}-\mathrm{H}$ & & 0,237 & 0,211 \\
\hline 6 & $\mathrm{~F}-\mathrm{H}$ & & 0,37 & 0,000 \\
\hline 7 & $\mathrm{G}-\mathrm{H}$ & & 0,363 & 0,011 \\
\hline
\end{tabular}

Pada Tabel 9 hasil dari pengujian effect size $\left(\mathrm{f}^{2}\right)$ terhadap 7 jalur variabel. Variabel yang memiliki nilai pengaruh kecil dibawah 0,14 adalah A (usefulness), B (ease of use), C (content), D (accuracy), F (ease), G (timeless). Sedangkan variabel E (Format) merupakan hasil variabel yang memiliki pengaruh sedang dari effect size $\left(\mathrm{f}^{2}\right)$, sehingga ketika variabel $\mathrm{E}$ (Format) dikeluarkan dari jalur struktural akan berpengaruh sedang terhadap variabel independen yang berdasarkan pada tabel 3, dalam analisis jalur struktural.

\subsection{Hipotesis}

Hasil hipotesis dapat dilihat pada tabel 10 sebagai berikut

Tabel 10. Hasil Hipotesis Kepuasan Penguna

\begin{tabular}{|c|c|c|c|}
\hline \multicolumn{2}{|r|}{ Hipotesis } & $\begin{array}{c}\mathrm{T}- \\
\text { Statistik }\end{array}$ & Hasil \\
\hline $\begin{array}{l}\mathrm{H} \\
1\end{array}$ & 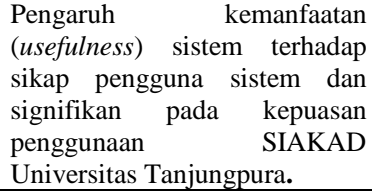 & 0,191 & $\begin{array}{c}\mathrm{Ha} \\
\text { ditolak }\end{array}$ \\
\hline $\begin{array}{l}\mathrm{H} \\
2\end{array}$ & \begin{tabular}{lr} 
Pengaruh & \multicolumn{2}{c}{ kemudahan } \\
penggunaan & (ease of use) \\
terhadap sikap pengguna \\
sistem dan & signifikan pada \\
kepuasan & penggunaan \\
SIAKAD & Universitas \\
Tanjungpura. & \\
\end{tabular} & 0,699 & $\begin{array}{c}\mathrm{Ha} \\
\text { ditolak }\end{array}$ \\
\hline $\begin{array}{l}\mathrm{H} \\
3\end{array}$ & 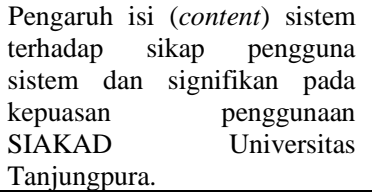 & 2,736 & $\begin{array}{c}\mathrm{Ha} \\
\text { diterim } \\
\mathrm{a}\end{array}$ \\
\hline $\begin{array}{l}\mathrm{H} \\
4\end{array}$ & $\begin{array}{l}\text { Pengaruh akurasi (accuracy) } \\
\text { sistem terhadap sikap } \\
\text { pengguna sistem dan signifikan } \\
\text { pada kepuasan penggunaan } \\
\text { SIAKAD } \\
\text { Tanjungpura. }\end{array}$ & 0,065 & $\begin{array}{c}\mathrm{Ha} \\
\text { Ditolak }\end{array}$ \\
\hline
\end{tabular}

Tabel 10. Hasil Hipotesis Kepuasan Penguna SIAKAD (lanjutan).

\begin{tabular}{|c|c|c|c|}
\hline \multicolumn{2}{|r|}{ Hipotesis } & \multirow{2}{*}{$\begin{array}{c}\text { T- } \\
\text { Statistik } \\
6,339\end{array}$} & \multirow{2}{*}{$\begin{array}{c}\text { Hasil } \\
\\
\mathrm{Ha} \\
\text { diterima }\end{array}$} \\
\hline $\begin{array}{l}\mathrm{H} \\
5\end{array}$ & $\begin{array}{lrr}\text { Pengaruh format } & \text { (format) } \\
\text { sistem terhadap } & \text { sikap } \\
\text { pengguna } & \text { sistem dan } \\
\text { signifikan pada kepuasan } & \text { kenggunaan } & \text { SIAKAD } \\
\text { pengunaritas Tanjungpura. } & \\
\text { Universitan }\end{array}$ & & \\
\hline $\begin{array}{l}\mathrm{H} \\
6\end{array}$ & $\begin{array}{l}\text { Pengaruh kemudahan (ease) } \\
\text { terhadap sikap pengguna } \\
\text { sistem dan signifikan pada } \\
\text { kepuasan } \\
\text { SIAKAD penggunaan } \\
\text { Tanjungpura. }\end{array}$ & 0,146 & $\begin{array}{c}\mathrm{Ha} \\
\text { ditolak }\end{array}$ \\
\hline $\begin{array}{l}\mathrm{H} \\
7\end{array}$ & $\begin{array}{l}\text { Pengaruh ketepatan waktu } \\
\text { (timeless) sistem terhadap } \\
\text { sikap pengguna sistem dan } \\
\text { signifikan pada kepuasan } \\
\text { penggunaan } \\
\text { Universitas Tanjungpura. }\end{array}$ & 1,667 & $\begin{array}{c}\mathrm{Ha} \\
\text { ditolak }\end{array}$ \\
\hline $\begin{array}{l}\mathrm{H} \\
8\end{array}$ & $\begin{array}{l}\text { Pengaruh sikap } \text { (attitude) } \\
\text { pengguna terhadap kepuasan } \\
\text { penggunaan } \\
\text { Universitas Tanjungpura. }\end{array}$ & 5,240 & $\begin{array}{c}\mathrm{Ha} \\
\text { diterima }\end{array}$ \\
\hline
\end{tabular}

Pada Tabel 10 terdapat 3 dari 8 hipotesis yang telah memenuhi kepuasan pengguna SIAKAD yaitu hasil hipotesis isi (content), format (format) dan sikap (attitude) Sehingga hipotesis $\mathrm{H}_{0}$ ditolak, artinya ada pengaruh positif $\left(\mathrm{H}_{\mathrm{a}}\right.$ diterima) pada variabel isi (content), format (format), sikap (attitude). Selanjutnya 5 dari 8 hipotesis belum memenuhi kepuasan pengguna, sehingga hipotesis $\mathrm{H}_{0}$ diterima, artinya tidak ada pengaruh positif $\left(\mathrm{H}_{\mathrm{a}}\right.$ ditolak $)$ pada variabel kemanfaatan (usefulness), kemudahan penggunaan (ease of use), akurasi (accuracy), kemudahan (ease), dan ketepatan waktu (timeless).

\section{PENUTUP}

\section{a. Kesimpulan}

Berdasarkan pada hasil penelitian evaluasi kepuasan pengguna SIAKAD Universitas Tanjungpura menggunakan integrasi Technology Acceptance Model (TAM) dan End-User Computing Satisfaction (EUCS). yang telah dilakukan maka dapat diambil kesimpulan sebagai berikut:

1. Penelitian ini mengukur tingkat kepuasan pengguna melalui 8 kriteria hasil integrasi TAM dan EUCS yaitu kemanfaatan, kemudahan penggunaan, akurasi, kemudahan, dan ketepatan waktu, isi, format dan sikap. Penelitian ini menghasilkan t-statistik yang diterima pada variabel content, format, attitude, dengan masing-masing nilai 
yaitu 2,733, 6,339, dan 5,240. Hasil path coefficients yang bersesuaian dengan nilai t-statistik yaitu content, format, dan attitude, masing-masing nilai tersebut adalah 0,217, 0,484, dan 0,372, semakin tinggi nilai t-statistik maka nilai path coefficients akan bernilai besar. Nilai $R$ Square pada variabel user satisfaction dengan klasifikasi lemah yaitu 0,14 dan Nilai effect size $\left(\mathrm{f}^{2}\right)$ pada variabel format 0,211 yang memiliki pengaruh sedang.

2. Hasil nilai t-statistik pada 5 variabel yang belum memenuhi kepuasan pengguna adalah pada variabel usefulness, ease of use, accuracy, ease, dan timeless, dengan nilai masingmasing yaitu 0,191, 0,699, 0,065, 0,146, dan 1,667. Nilai path coefficients yang bersesuaian dengan nilai t-statistik adalah $0,011,0,048,0,004,0,012$, dan 0,100 , nilai t-statistik yang rendah maka nilai path coefficients akan bernilai rendah.

3. Variabel yang belum memenuhi standar pengukuran disebabkan oleh beberapa faktor, diantaranya luasnya penyebaran populasi pada ruang lingkup menyeluruh di setiap fakultas Universitas Tanjungpura, dan penyebaran kuisioner yang kebanyakan dilakukan secara online sehingga tidak bertemu langsung dengan responden $(85$ $\%$ tersebar secara online) dan tidak didampingi dalam pengisian kuisioner, hal ini memungkinkan terdapat penafsiran yang berbeda oleh responden terhadap item pertanyaan pada kuesioner.

\section{b. Saran}

Perlu dilakukan penelitian lebih lanjut mengenai kepuasan pengguna dengan mengkombinasikan model variabel lain yang lebih beragam. Lebih memperhatikan tata bahasa sehingga kuisioner mudah dipahami agar tidak terjadi salah pemahaman mengenai indikator pertanyaan pada kuisioner atau perlu dilakukan pendampingan pada setiap penyebaran. Sehingga dapat memberikan kontribusi hasil dalam evaluasi kepuasan pengguna sistem yang lebih baik bagi penelitian di bidang sistem informasi.

\section{REFERENSI}

[1] Sutabri, Tata. 2012. Konsep Sistem Informasi. Yogyakarta: Andi Offset.

[2] Machmud, Rizan. 2018. Kepuasan Pengguna Sistem Informasi (Studi kasus pada T3-online). Gorontalo : Ideas Publishing.

[3] Santoso, Ananda dan S, Pritanto. 2007. Kamus Lengkap Bahasa Indonesia. Surabaya : Kartika

[4] Davis, F. 1986. A Technology Acceptance Model for Empirically Testing New End User Infoemation System : Theory and Result.

[5] Linders, S. 2006. "Using the Technology Acceptance Model in determining strategies for implementation of mandatory IS." 4th Twente Student Conference on IT. Enschede: University of Twente, Faculty of Electrical Engineering, Mathematics and Computer Science.

[6] Doll, W, J., Deng, X., Raghunathan, T, S., Torkzadeh, G., and Xia, W. 2004. The Meaning and Measurement of User Satisfaction : A Multigroup Invariance Analysis of the End-User Computing Satisfaction Instrument. Journal of Management Information System. Vol. 21, No. 1, 227-262.

[7] Mustafa, Z, EQ. 2009. Mengurai Variabel Hingga Instrumentasi. Yogyakarta : Graha Ilmu.

[8] Sugiyono. 2017. Statistika Untuk Penelitian. Bandung : Alfabeta

[9] Sugiarto. Siagian, D. Sunaryanto, T, L,. Oetomo, S. D. 2001. Teknik Sampling. Jakarta : Gramedia Pustaka Utama.

[10] Istiarni, Atin. 2016. "Analisis Penerimaan Sistem Informasi Perpustakaan Berbasis Technology Acceptance Model dan End-User Computing Satisfaction di Perpustakaan Universitas Muhammadiyah Magelang." Tesis. UIN Sunan Kalijaga. Yogyakarta.

[11] Ghozali, Imam. 2014. Struktural Equation Modeling (Metode Alternatif Dengan Partial Least Square (PLS)). Semarang: Universitas Diponegoro. 
[12] Sekundera, C. 2006. Analisis Pengguna Akhir Dengan Menggunakan Technology Acceptance Model dan End User Computing Satisfaction Terhadap Penerapan Sistem Core Banking Pada Bank ABC. Tesis. Universitas Diponegoro. Semarang.

[13] Anwar, Ahmad. 2017. Analisis Penerimaan Pemusta Terhadap Institutional Repository Berbasis EPrints di Perpustakaan Universitas Aisyiyah Yogyakarta Sebuah Pendekatan Integratif Antara Technology Acceptance Model Dan End User Computing Satisfaction. Tesis. UIN Sunan Kalijaga. Yogyakarta

[14] Fitriansyah, A., Harris, I. 2018. Penerapan Dimensi EUCS (End User Computing Satisfaction) Untuk Mengevaluasi Tingkat Kepuasan Pengguna Situs Web. Prosiding Konferensi Nasional Sistem Informasi 2018. Pangkalpinang : 8-10 Maret 2018. 51-55.

[15] Laily, Nur, NH., 2019. Analisis Penerimaan Pengguna Sistem Informasi Manajemen DAPODIK PAUD DIKMAS Menggunakan Model TAM dan EUCS Pada PAUD Kecamatan Cilincing, Skripsi. UIN Syarif Hidayatullah Jakarta.

[16] Meha, H, R. 2019. "Analisis Kepuasan Pengguna Sistem Informasi Akademik di UIN Syarif Hidayatullah Jakarta." Skripsi. UIN Syarif Hidayatullah Jakarta. 